\title{
Loss Reduction of Modular Multilevel Converter with Balancing Circuit for Low-Voltage Grid Converter
}

\author{
Takuro Arai ${ }^{* a)}$ \\ Member, \\ Kei Sekiguchi* \\ Member \\ Hiroshi Mochikawa* Senior Member, \\ Kenichiro Sano** Member \\ Hideaki Fujita** Member
}

This study proposes a modular multilevel converter by applying a balancing circuit with a resistor for a low-voltage grid converter. The proposed balancing circuit, which is controlled by the same gate signal as that of the main switch, can reduce the loss of the additional balancing circuit and the current rating of the balance switch without the need for additional the cell capacitors. Only one voltage sensor per converter arm is required to automatically balance the cell capacitor voltages. The experimental results indicate that the cell capacitor voltages are well balanced during a rated operation of $10 \mathrm{~kW}$ and a high efficiency of up to $99.2 \%$ is achieved, which is almost the same as that without a balancing circuit.

Keywords: modular multilevel converter, MMC, grid-connected converter, cell capacitor, balance circuit, Si-MOSFET

\section{Introduction}

A modular multilevel converter (MMC) can easily generate high voltage with low distortion by increasing the number of cells in a converter arm. For this reason, it has been studied mainly for high-voltage applications such as high-voltage direct current (HVDC), and there have been practical use in recent years ${ }^{(1)-(4)}$. In the case of an IGBT, which is generally used for high-voltage applications, connecting a higher number of switching devices in series to reduce the voltage rating of the devices increases the total on-state voltage. On the other hand, the on-resistance of MOSFET, which is generally used for low-voltage converters, is proportional to the breakdown-voltage to the 2.5 th power. Therefore, multilevel converter with the lower voltage MOSFETs can reduce the conduction losses rather than using high voltage devices ${ }^{(5)}$. The multilevel converter is also possible to downsize AC filters because of the multilevel output. Applying an MMC to low-voltage grid-connected converters of $200 \mathrm{~V}$ and $400 \mathrm{~V}$, it is possible to use Si-MOSFETs with a low breakdown voltage of $100 \mathrm{~V}$. The low voltage MOSFET, which is mainly used for vehicles, is inexpensive because its market volume is particularly large. Therefore, using a higher number of devices is not considered as a significant problem, and the multilevel converter using a low-voltage MOSFET is more cost-effective than a two-level converter using conventional

a) Correspondence to: Takuro Arai. E-mail: takuro.arai@ toshiba. co.jp

* Toshiba Infrastructure Systems and Solutions Corporation

1, Toshiba-cho, Fuchu, Tokyo 183-8511, Japan

${ }^{* *}$ Department of Electrical and Electronic Engineering, Tokyo Institute of Technology

NE12, 2-12-1, O-okayama, Meguro-ku, Tokyo 152-8522, Japan
IGBT. In a previous study, it is reported from our research group that the MMC using a low-voltage Si-MOSFET for a grid-connected converter with a rated voltage of $200 \mathrm{~V}$ and $10 \mathrm{kVA}$ achieved a conversion efficiency of more than $99 \%{ }^{(6)}$.

It is necessary for MMCs to keep the voltage of the capacitors of all cells at the same level. A balance of the capacitor voltage between converter arms can be controlled by the circulating current in the $\mathrm{MMC}^{(7)(8)}$. On the other hand, the balance of the capacitor voltage in the same converter arm (individual balance) is achieved using the degrees of freedom of the output voltage of each cell. Some methods detect the voltage of each capacitor and feed it back to the duty ratio or firing angle of the corresponding cell ${ }^{(8)(9)}$. There are also sorting methods that calculate the number of cells to be inserted, based on the output voltage reference value of the converter arm. In the sorting algorithm, the voltage balance realizes by determining which cells should be inserted based on each cell capacitor voltage $^{(1)(7)(10)-(12)}$. However, these methods require both an isolated voltage sensor and an AD converter that detects all cell capacitor voltages. Although other control methods that estimate the capacitor voltage without voltage sensor have been proposed ${ }^{(13)-(18)}$, estimating capacitor voltages requires a high-speed CPU and FPGA for excessive amounts of calculation.

The cost weight of the control circuit and auxiliary circuit such as voltage sensor inevitably increases because the low voltage grid-connected converters usually has small rated power. Hence, in terms of cost, it is more effective to add a small balancing circuit for individual voltage balance than using multiple detection circuits and costly CPUs and FPGA. Some balancing circuit methods for the MMC have been proposed. Using the principles of Marx generator and switched capacitor, changing the series-parallel connection of the cell 
capacitors make it possible to balance the cell capacitor voltage of the MMC without active control ${ }^{(19)-(25)}$. A Marx multilevel inverter ${ }^{(20)(21)}$, which is based on the principle of the Marx generator, can balance each cell capacitor voltage individually without voltage sensors or special controls. A circuit configuration of the Marx multilevel inverter can be described as the MMC with additional switches (balancing circuits) connected between the cells. In addition, Ref. (25) proposed a balancing circuit composed of diodes and reactors instead of switching devices. However, with these balancing circuits, there are fundamental losses associated with the charge/discharge of the capacitors, which make them less efficient than when individual balancing control is applied. As a result, the conversion efficiency is about 90 98\% (20)(22)-(25). Although the capacitance of the cell capacitor is increased to reduce the losses caused by the charge/discharge of the capacitors, it is not very practical because it makes the circuit larger ${ }^{(26)}$.

In this paper, a balancing circuit with a resistor is proposed to reduce the loss of the balancing circuit. The advantage of this circuit is that the loss of the balancing circuit can be very small. The balancing circuit consists of a small current rated devices and resistors without feedback control or voltage sensor. The added resistor can reduce the peak current of the balancing circuit, and the current rating of the added switch for balancing circuit can be reduced to $0.4 \%$ of the main switches or less. The gate signal of the added switching device is the same as the gate signal of the main switch with only an adjustment of the delay time, hence a simple control circuit can be used. Besides, it is possible to reduce the losses caused by the charge/discharge of the capacitors by designing an appropriate resistance value. Therefore, there is no need to increase the cell capacitance value. In the experiment, the proposed balancing circuit is connected to choppercells of NPC-MMC (Neutral-point- clamped MMC) ${ }^{(6)(27)}$ of $10 \mathrm{~kW}$. The experimental results indicate that the cell capacitor voltages are well balanced during a rated operation and a high efficiency of up to $99.2 \%$ is achieved, which is almost the same as that without a balancing circuit.

\section{MMC with a Balancing Circuit}

\subsection{Circuit Configuration and Operating Principle}

Figure 1 shows an MMC with a balancing circuit. The converter arm has chopper-cells connected in series, and it connects to the AC system via the buffer reactor. Each choppercell is interconnected by the balancing circuit. Figure 2 illustrates the circuit configuration of the converter arm with the proposed balancing circuit. The chopper-cells are composed of a switching leg with two main switches, $S_{P}$ and $S_{N}$, and a single cell capacitor. The number of series-connected cell capacitors, which determines the amplitude of the arm voltage $v_{\text {arm }}$, is determined based on a switching states of the main switches $S_{P}$ and $S_{N}$. When the main switch $S_{N}$ is turned on, cell capacitors are inserted in series. When the $S_{P}$ is turned on, cell capacitor is bypassed. The balancing circuit consists of balance switch $\mathrm{S}_{\mathrm{B}}$ and balance resistor $R_{B}$. If the balance switch $S_{B}$ is connected to the negative side of the cell capacitor, the source terminal of $S_{B}$ and $S_{N}$ become common. Therefore, the gate drive power of $S_{B}$ can be supplied from the gate power supply of $S_{N}$. As a result, there is no need to

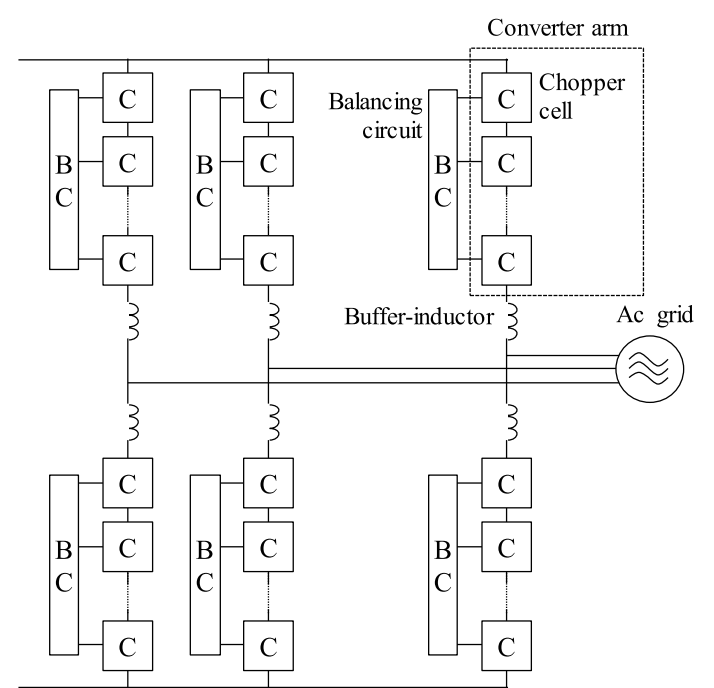

Fig. 1. Modular multilevel converter with balancing circuit

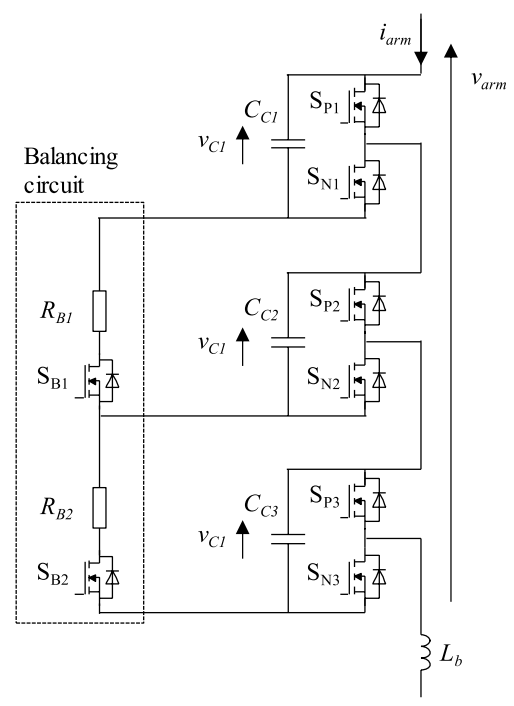

Fig. 2. Circuit configuration of the converter arm with balancing circuit

add a new circuit of the gate power supply for the additional switch of $S_{B}$. However, a gate drive circuit for $S_{B}$ is required because the gate signal is different.

When a phase-shifted PWM is applied to the MMC and it is operated with a carrier frequency higher than a few $\mathrm{kHz}$, in principle, the power flow between cell capacitors due to switching is canceled out in one switching cycle. Therefore, the voltage difference between cell capacitors in the same arm does not occur ${ }^{(28)}$. However, in practice, there is a voltage deviation (unbalanced voltage) caused by a variation of a characteristic of the device and the capacitor, and so on. The aim of the balancing circuit is to suppress this unbalanced voltage. Cell capacitors that are not connected in series can be connected in parallel to the other cell capacitor via the balancing circuit. For example, when $S_{P 1}$ and $S_{B 1}$ are on, it is possible to connect $C_{C 1}$ and $C_{C 2}$ in parallel, and when $\mathrm{S}_{\mathrm{P} 2}$ and $\mathrm{S}_{\mathrm{B} 2}$ are on, it is possible to connect $C_{C 2}$ and $C_{C 3}$ in parallel. As a result, the voltage of all cell capacitors in the arm$C_{C 1}, C_{C 2}$, and $C_{C 3}$ - can be equalized automatically without voltage sensors nor feedback control for each cell capacitor. 
Moreover, the balance resistor reduces the inrush current when two cell capacitors are connected in parallel. Therefore, the current rating of the balance switch $\mathrm{S}_{\mathrm{B}}$ can be smaller than that of the main switches $S_{P}$ and $S_{N}$.

\subsection{Switching Pattern and Control Figure 3 shows} a control diagram of a converter arm with a balancing circuit. A voltage sensor is connected to only a single cell capacitor of each converter arm, and this cell is called a representative cell. The duty ratio of each cell is calculated by dividing the voltage reference value of the converter arm- $-v_{\text {arm }} *$ - by the capacitor voltage of the representative cell ( $v_{c 1}$ in Fig. 3 ). The same duty ratio is given to all cells. Note that $v_{\text {arm }} *$ can be calculated by the conventional voltage/current control of $\mathrm{MMC}^{(7)(8)}$. The phase-shifted PWM (PS-PWM) is applied for the modulation. Since the balancing circuit automatically maintains the same voltage in all cell capacitors of the converter arm, there is no need to use complex feedback control and sorting algorithm, which require a large amount of calculations. Therefore, this control system does not require a voltage sensor to detect the cell capacitor voltage of the cells other than the representative cell or an AD converter.

Since the same gate signal as the main switch $S_{P}$ is applied to the gate of balance switch $\mathrm{S}_{\mathrm{B}}$, the control circuit does not require additional PWM controllers or gate signal interface. Note that $S_{N}$ is given the complementary signal of $S_{P}$ with dead time added.

Table 1 shows the switching patterns of the circuit of Fig. 2. If the cell capacitor voltage is $v_{C}\left(=v_{C 1}=v_{C 2}=v_{C 3}\right)$, the arm voltage $v_{\text {arm }}$ outputs four levels of voltage, from 0 to $3 v_{C}$, depending on the on/off state of main switches $\mathrm{S}_{\mathrm{P} 1}, \mathrm{~S}_{\mathrm{P} 2}$, and

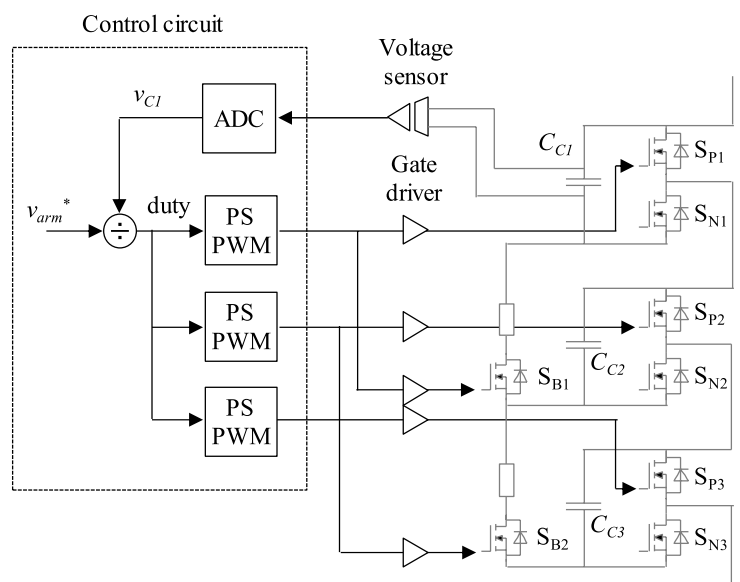

Fig. 3. Control diagram of MMC with balancing circuit

Table 1. Switching patterns of MMC with balancing circuit consisting of three chopper cells per one converter arm

\begin{tabular}{|c|c|c|c|c|}
\hline $\mathrm{S}_{\mathrm{P} 1}$ & $\mathrm{~S}_{\mathrm{P} 2}$ & $\mathrm{~S}_{\mathrm{P} 3}$ & $v_{\text {arm }}$ & $\begin{array}{c}\text { Parallel } \\
\text { connected }\end{array}$ \\
\hline $\mathrm{S}_{\mathrm{B} 1}$ & $\mathrm{~S}_{\mathrm{B} 2}$ & 1 & 0 & $C_{C 1} C_{C 2} C_{C 3}$ \\
\hline 1 & 1 & 1 & $v_{C}$ & $C_{C 1} C_{C 2} C_{C 3}$ \\
\hline 1 & 1 & 0 & $v_{C 2} C_{C 3}$ \\
\hline 0 & 1 & 1 & $v_{C}$ & ${ }$ \\
\hline 1 & 0 & 1 & $v_{C}$ & $C_{C 1} C_{C 2}$ \\
\hline 1 & 0 & 0 & $2 v_{C}$ & $C_{C l} C_{C 2}$ \\
\hline 0 & 1 & 0 & $2 v_{C}$ & $C_{C 2} C_{C 3}$ \\
\hline 0 & 0 & 1 & $2 v_{C}$ & $N / A$ \\
\hline 0 & 0 & 0 & $3 v_{C}$ & $N / A$ \\
\hline
\end{tabular}

$\mathrm{S}_{\mathrm{P} 3}$. The same gate signal as $\mathrm{S}_{\mathrm{P} 1}$ can be applied to the balance switch $S_{\mathrm{B} 1}$, and the same gate signal as $\mathrm{S}_{\mathrm{P} 2}$ can be applied to $\mathrm{S}_{\mathrm{B} 2}$.

\section{Design of the Balancing Circuit to Reduce its Loss}

This chapter details the analysis and design of the balancing circuit. The voltage difference between cell capacitors has two components: deviation caused by the variation of the devices (unbalanced voltage) and voltage ripple caused by the switching operation (switching ripple voltage). The original role of a balancing circuit is controlling the unbalanced voltage, which gradually increases due to a slight dc current accumulated in the cell capacitors. On the other hand, the balancing circuit does not need to suppress the switching ripple voltage. However, as the balancing circuit works for any voltage difference, including the voltage difference due to the switching ripple voltage, unnecessary current flows in the balancing circuit and the loss increases. This kind of loss is expressed here as loss due to switching ripple voltage. The following sections show that it is possible to reduce losses due to switching ripple voltage significantly and suppress the unbalanced voltage by designing the balance resistor appropriately.

3.1 Switching Mode of the Balancing Circuit Figure 4 shows four switching modes with two cells. In Mode $\mathrm{A}, \mathrm{S}_{\mathrm{P} 1}, \mathrm{~S}_{\mathrm{P} 2}$, and balance switch $\mathrm{S}_{\mathrm{B} 1}$ are on, and the number of series connections is zero. Since $C_{C 1}$ and $C_{C 2}$ are connected in parallel through $R_{B}$, the balance current $i_{B}$ flows in the direction of reducing the voltage difference between $v_{C 1}$ and $v_{C 2}$.

In Mode $\mathrm{B}, \mathrm{S}_{\mathrm{N} 1}$ and $\mathrm{S}_{\mathrm{P} 2}$ are on, and the balance switch $\mathrm{S}_{\mathrm{B} 1}$ is off, with no balance current flowing. In this case, since arm current $i_{\text {arm }}$ flows in $C_{C 1}, v_{C 1}$ increases or decreases, whereas $v_{C 2}$ does not change because the current of $C_{C 2}$ is zero. Therefore, the voltage difference between $v_{C 1}$ and $v_{C 2}$ is increased by the switching operation in Mode B.

In Mode $\mathrm{C}, \mathrm{S}_{\mathrm{P} 1}, \mathrm{~S}_{\mathrm{N} 2}$, and balance switch $\mathrm{S}_{\mathrm{B} 1}$ are on, and $v_{\text {arm }}=v_{C 2}$. In this mode, the arm current is divided into $C_{C 1}$ and $C_{C 2}$. However, since $C_{C 1}$ and $R_{B}$ are connected in series,

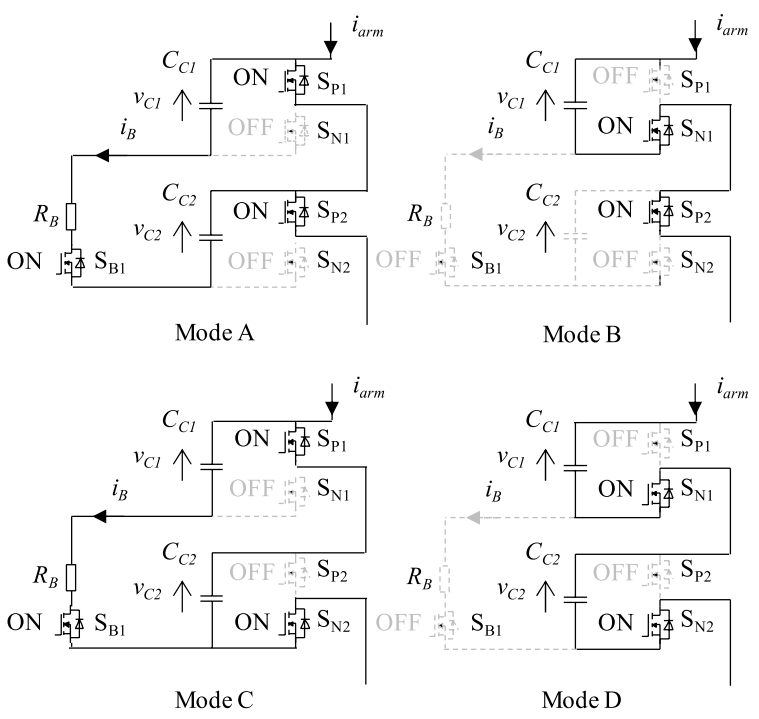

Fig. 4. Switching modes of balancing circuit 
the balance current is proportional to the difference between $v_{C 1}$ and $v_{C 2}$.

Finally, in Mode D, $\mathrm{S}_{\mathrm{N} 1}$ and $\mathrm{S}_{\mathrm{N} 2}$ are on, and the balance switch $S_{\mathrm{B} 1}$ is off, with no balance current flowing. Because the arm current flows to both $C_{C 1}$ and $C_{C 2}$, the voltage difference does not change.

3.2 Analysis of the Loss due to Switching Ripple Voltage This section analyzes the loss in the balancing circuit caused by the voltage difference due to switching ripple voltage. This analysis assumes that the unbalanced voltage has been suppressed considerably. It is assumed that the period of Mode $\mathrm{B}$ is $t_{B}$, the arm current during this period is constant and represented as $i_{\text {arm }}$, and the voltage difference when Mode B starts is zero. The voltage difference that occurs during Mode B is expressed as follows:

$$
\Delta v_{C(B)}=v_{C 1(B)}-v_{C 2(B)}=\frac{i_{a r m} t_{B}}{C_{C}}
$$

where the capacitance of the cell capacitors is $C_{C}=C_{C 1}=$ $C_{C 2}$.

The voltage difference that occurs during Mode $\mathrm{B}$ decreases in Mode $A$ or $C$, in which the balance switch $S_{B 1}$ turns on. First, the case that the voltage difference decreases in Mode A will be discussed. Defining voltage difference when Mode $\mathrm{A}$ starts as $\Delta V_{C 0(\mathrm{~A})}$, the balance current is expressed as follows:

$$
i_{B(A)}=-\frac{\Delta V_{C O(A)}}{R_{B}} e^{-\frac{t}{\tau}}
$$

where, $R_{B}$ is the balance resistance value. $\tau$ is a time constant of the balancing circuit that is expressed as follows:

$$
\tau=\frac{R_{B} C_{C}}{2}
$$

Given that the initial value of the voltage difference in Mode A is $\Delta V_{C 0(\mathrm{~A})}=\Delta v_{C(\mathrm{~B})}$, the average loss in balance resistance during one switching cycle becomes as follows:

$$
\begin{aligned}
P_{s r(A)} & =\frac{1}{t_{s w}} \int_{0}^{t_{A}} R_{B} i_{B(A)}{ }^{2} d t \\
& =\frac{f_{s w}}{4 C_{C}}\left(1-e^{-\frac{2 t_{A}}{\tau}}\right) t_{B}{ }^{2} i_{a r m}{ }^{2}
\end{aligned}
$$

where, $t_{A}$ is the period of Mode A.

Second, the case that the voltage difference decreases in Mode $\mathrm{C}$ will be analyzed. The balance current of Mode $\mathrm{C}$ is expressed as follows:

$$
i_{B(C)}=-\frac{\Delta V_{C 0(C)}}{R_{B}} e^{-\frac{t}{\tau}}+\frac{i_{\text {arm }}}{2}\left(1-e^{-\frac{t}{\tau}}\right) \ldots \ldots \ldots \ldots
$$

where, $\Delta V_{C 0(\mathrm{C})}$ is the initial voltage difference value of Mode C. The first term of equation (5) shows the current generated by the initial voltage difference $\Delta V_{C 0(\mathrm{C})}$ and the second term means that a part of the arm current flows in the balancing circuit. If the same duty ratio is given to each cell as in Fig. 3, the period of Mode $C$ becomes $t_{C}=t_{B}$. Supposing the initial voltage difference of Mode $\mathrm{C}$ is $\Delta V_{C 0(\mathrm{C})}=\Delta v_{C(\mathrm{~B})}$, the loss in the balance resistor is expressed as follows:

$$
P_{s r(C)}=\frac{1}{t_{s w}} \int_{0}^{t_{C}} R_{B} i_{B(C)}{ }^{2} d t
$$

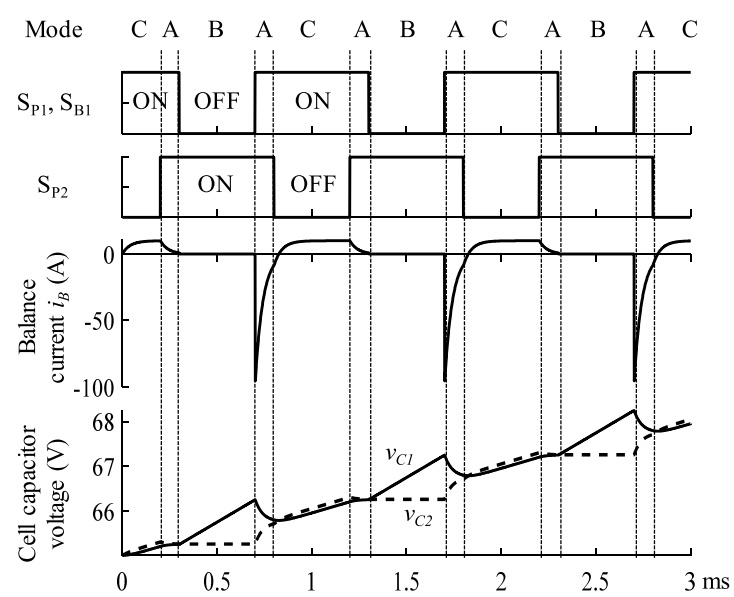

Fig. 5. Waveforms of balance current and cell capacitor voltages in case of HSB

$$
\begin{aligned}
= & f_{s w}\left[\frac{1}{4 C_{C}}\left(1-e^{-\frac{2 t_{B}}{\tau}}\right) t_{B}{ }^{2}\right. \\
& +\frac{t_{B} R_{B}}{2}\left(e^{-\frac{t_{B}}{\tau}}-\frac{e^{-\frac{2 t_{B}}{\tau}}}{2}\right) \\
& \left.+\frac{\tau R_{B}}{2}\left(e^{-\frac{t_{B}}{\tau}}-\frac{e^{-\frac{2 t_{B}}{\tau}}}{4}-\frac{3}{4}\right)\right] i_{\text {arm }}{ }^{2} \ldots \ldots \ldots
\end{aligned}
$$

Next, the relationship between the time constant $\tau$ and the loss in the balancing circuit will be considered.

(1) The case of HSB (High-Speed Balancing)

The case of HSB: High-Speed Balancing $\left(t_{s w} / \tau \gg 1\right)$, wherein the time constant $\tau$ is considerably shorter than the switching period $t_{s w}=1 / f_{s w}$. Figure 5 shows waveforms of the balance current and cell capacitor voltages in HSB. During Mode B, there is a voltage difference due to switching ripple voltage. During Mode $\mathrm{A}$, the cell capacitors are charged/discharged with the time constant $\tau$ via the balancing circuit, and the voltage difference decreases. Then, the balance current flows in the balance resistor and causes a loss.

When the switching ripple voltage is discharged in Mode $\mathrm{A}$, the loss generated by the switching ripple voltage can be approximated to be as follows:

$$
P_{s r-H S B(A)} \approx \frac{f_{s w}}{4 C_{C}} t_{B}^{2} i_{\text {arm }}^{2}
$$

where Eq. (4) is approximated with $e^{-2 t_{A} / \tau} \rightarrow 0$ by assuming $\tau \ll t_{A}$ in HSB. Considering that $t_{B}$ is inversely proportional to $f_{s w}\left(t_{B} \propto 1 / f_{s w}\right)$, the loss can be reduced by increasing $C_{C}$ and $f_{s w}$. However, it also increases the switching loss of the main switch and the volume of the cell capacitors.

Similarly in Mode A, providing that Eq. (6) is approximated with $\tau \ll t_{B}$, the loss discharged in Mode $\mathrm{C}$ is calculated as follows:

$$
P_{s r-H S B(C)} \approx \frac{f_{s w}}{4 C_{C}} t_{B}^{2} i_{a r m}^{2}
$$

(2) The case of LSB (Low-Speed Balancing)

The case of LSB: Low-Speed Balancing $\left(t_{s w} / \tau \ll 1\right)$, wherein the time constant $\tau$ is considerably longer than the switching period $t_{s w}$. Figure 6 shows waveforms of the LSB. The voltage difference generated during Mode B does not decrease immediately when it becomes Modes A and $\mathrm{C}$ because 


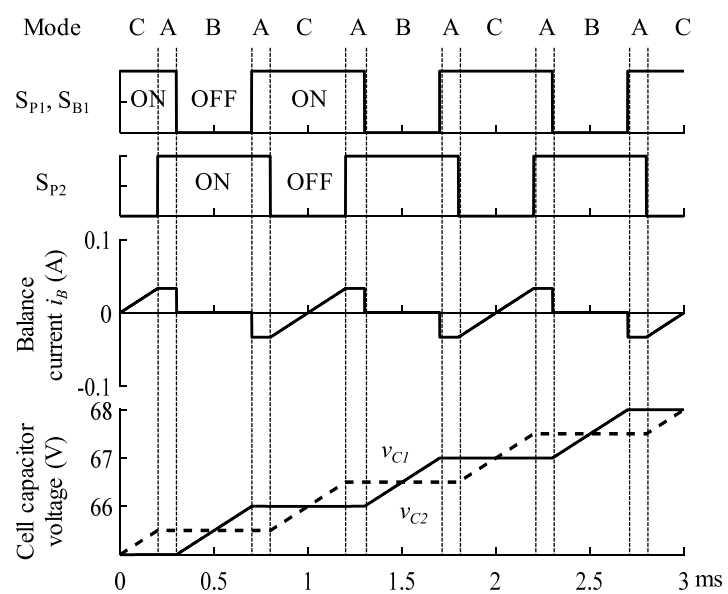

Fig. 6. Waveforms of balance current and cell capacitor voltages in case of LSB

the time constant is longer than the switching period.

In the case of LSB, where $\tau \gg t_{A}$ and $\tau \gg t_{B}$, applying first-order approximation to Eqs. (4) and (6), the loss generated by the switching ripple voltage is calculated as follows:

$$
\begin{aligned}
P_{s r-L S B(A)} & \approx \frac{f_{s w}}{R_{B} C_{C}{ }^{2}} t_{A} t_{B}{ }^{2} i_{a r m}{ }^{2} \\
P_{s r-L S B(C)} & \approx \frac{f_{s w}}{R_{B} C_{C}{ }^{2}} t_{B}{ }^{3} i_{a r m}{ }^{2} .
\end{aligned}
$$

Eqs. (9) and (10) indicate that if $R_{B}$ is set to a large value, the loss due to switching ripple voltage can be reduced. As a result, it is possible to reduce the loss without increasing $C_{C}$ and $f_{\text {sw. }}$.

3.3 Time Constant of Reducing the Unbalanced Voltage This section details the suppression of unbalanced voltage caused by the variation of the device. Shown in Eq. (2) and the first term of Eq. (5), the voltage difference decreases as exponential decay with time constant $\tau$ during Modes A and C. In the case of HSB, since the voltage difference is decreased almost completely within one switching cycle, the time constant of reducing the unbalanced voltage $\tau_{B}$ is equal to the time constant of the balancing circuit $\tau$. On the other hand, in the case of LSB, the voltage difference is hardly decreased during a single switching cycle. As the unbalanced voltage does not change during Modes B and D, wherein the balance switch is turned off, $\tau_{B}$ becomes longer than $\tau$. Here, it is assumed that $\tau_{B}$ is over several cycles of the grid.

In this analysis, the switching ripple voltage is ignored because it is canceled out in Modes B and C in LSB. The unbalanced voltage after one switching cycle can be obtained from Eqs. (2) and (5) as follows:

$$
\begin{aligned}
\Delta v_{C(t s w)} & =\Delta V_{C}+\frac{2}{C_{C}} \int_{0}^{t_{A}} i_{B(A)} d t+\frac{2}{C_{C}} \int_{0}^{t_{C}} i_{B(C)} d t \\
& =\Delta V_{C} e^{-\frac{t_{A}+t_{C}}{\tau}} \ldots \ldots \ldots \ldots \ldots \ldots \ldots \ldots \ldots \ldots \ldots \ldots \ldots
\end{aligned}
$$

where $\Delta V_{C}$ is the initial unbalanced voltage. Note that the second term of Eq. (5) is ignored because $\tau$ is much greater than $t_{s w}$. Eq. (11) indicates that the unbalanced voltage decreases in geometric progression. The number of switching times during period $t$ can be expressed as $f_{s w} t$. Therefore, the unbalanced voltage $\Delta v_{C}$ at time $t$ is calculated as follows:

$$
\Delta v_{C}=\Delta V_{C} \prod_{n=1}^{f_{S w} t} e^{-\frac{t_{A n}+t_{C n}}{\tau}}=\Delta V_{C} e^{-\frac{\left(\overline{T_{A}}+\bar{T}_{C}\right) f_{s w} t}{\tau}} \ldots \cdots \cdots
$$

where, $t_{A n}$ and $t_{C n}$ are the periods of Modes $\mathrm{A}$ and $\mathrm{C}$ in the n-th switching period, and $\overline{t_{A}}$ and $\overline{t_{C}}$ are the average value of $t_{A}$ and $t_{C}$ in the grid cycle. Since $\overline{t_{A}}+\overline{t_{C}}$ are the average value while the main switch $S_{\mathrm{P} 1}$ is turned on, the time constant of decreasing the unbalanced voltage with LSB is expressed as follows:

$$
\tau_{B}=\frac{\tau}{\left(\overline{t_{A}}+\overline{t_{C}}\right) f_{s w}}=\frac{\tau}{\overline{D_{S P}}}=\frac{R_{B} C_{C}}{2 \overline{D_{S P}}} \ldots \ldots \ldots \ldots \ldots
$$

where, $\overline{D_{S P}}$ is the time averaged duty ratio of $\mathrm{S}_{\mathrm{P} 1}$ in the grid cycle. Providing that the MMC is operating symmetrically, $\overline{D_{S P}}$ is equal to 0.5 . For example, in order to reduce the unbalanced voltage caused by a variation of devices or capacitance of cell capacitors, the balance resistor $R_{B}$ can be designed based on Eq. (13) so that $\tau_{B}$ is set to a few hundred milliseconds.

\section{Commutation of the Balance Circuit to Pre- vent Short-circuit of the Cell Capacitor}

As shown in Table 1, the gate signal of the balance switch is given by that of the same as the main switch. However, it is difficult to switch the balance switch exactly at the same time because the main switch and the balance switch may have different characteristics. When the switching of the main and the balance switches are not synchronized, the cell capacitor becomes short-circuit through the balancing circuit, and that causes further power loss. This section explains the commutation sequence to avoid this short-circuit.

Figure 7 shows the switching mode in the commutation. It illustrates the commutation from a state in which $S_{P 1}$ and $\mathrm{S}_{\mathrm{B} 1}$ are off, and $\mathrm{S}_{\mathrm{N} 1}$ is on, to another state in which $\mathrm{S}_{\mathrm{P} 1}$ and $\mathrm{S}_{\mathrm{B} 1}$ are on, and $\mathrm{S}_{\mathrm{N} 1}$ is off, when the arm current $i_{\text {arm }}$ is positive. (1) shows the state before the commutation, where $S_{P 1}$ and $S_{\mathrm{B} 1}$ are off, and $S_{\mathrm{N} 1}$ is on. (2) shows the dead time period, when $\mathrm{S}_{\mathrm{N} 1}$ turns off. The arm current flows into the body diode of $S_{N 1}$. In (3), $S_{P 1}$ is turned on before $S_{B 1}$ and the dead time ends. The arm current flows through $\mathrm{S}_{\mathrm{P} 1}$, but $\mathrm{S}_{\mathrm{B} 1}$ remains off, and no current flows in the balancing circuit. Lastly, in (4), $\mathrm{S}_{\mathrm{B} 1}$ is turned on. $C_{C 1}$ and $C_{C 2}$ are connected in parallel, and a balance current corresponding to the voltage deviation flows. Therefore, when the commutation is performed in the sequence (1) to (4), there is no short-circuit loss in the balance circuit. On the other hand, as shown in (3'), $\mathrm{S}_{\mathrm{B} 1}$ is turned on before $S_{P 1}$ when dead time ends. In this case, the arm current flows into the balance circuit so that the voltage applied to the balance resistor $R_{B 1}$ is equal to the voltage of $C_{C 2}$. This state can be seen as if $C_{C 2}$ is short-circuited through the balancing circuit. This short-circuiting of the cell capacitor continues until dead time ends. In the case of commutating from the state (4) to (1), it is also possible to prevent short-circuit loss in the balancing circuit by avoiding (3') and switching in the order of (3), (2), (1). In other words, $S_{\mathrm{B} 1}$ should be turned off before $S_{P 1}$. It should be noted that there is no short-circuit when the arm current is negative direction because the body diode of $\mathrm{S}_{\mathrm{N} 1}$ does not turn on. 


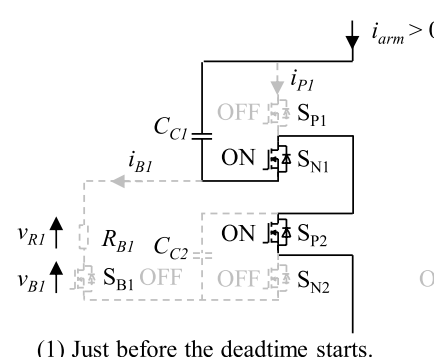

(1) Just before the deadtime starts.

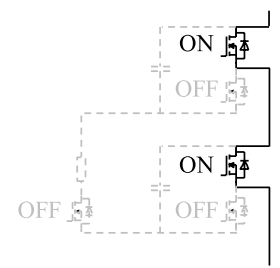

(3) Deadtime ends before balance switch turns on.

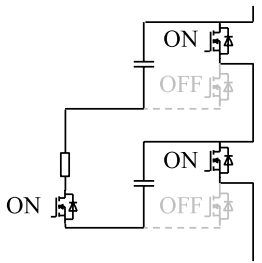

(4) Commutation is finished.

Fig. 7. Switching modes of commutation
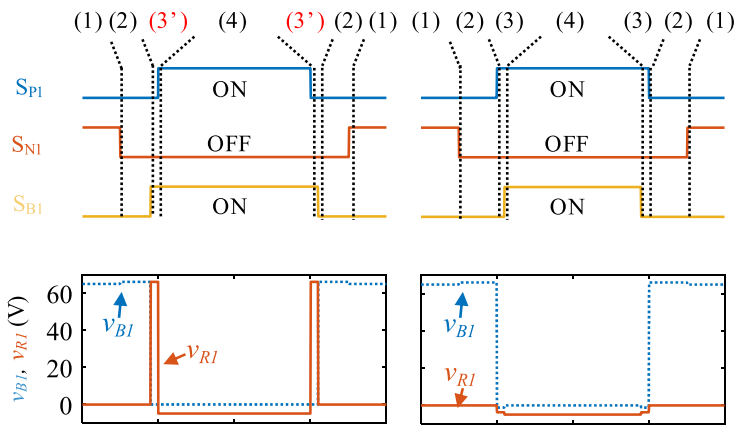

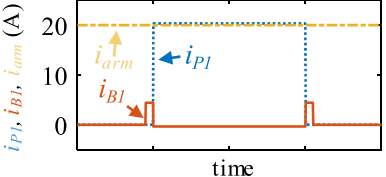

(a) Occurring the short circuit
(2) During the deadtime.

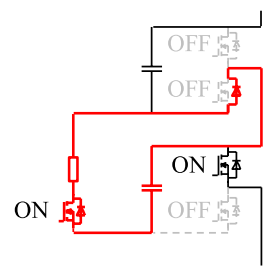

(3') Balance switch turns on before deadtime ends.
Fig. 8. Switching state and waveforms in the balance circuit during commutation

Figure 8 illustrates the switching sequence and waveforms of the balancing circuit during commutation when the cell voltages are equal. $v_{\mathrm{B} 1}$ and $i_{\mathrm{B} 1}$ are the voltage and current of the balance switch, $v_{R 1}$ is the voltage across the balance resistor, and $i_{P 1}$ is the current of $\mathrm{S}_{\mathrm{P} 1}$. Figure 8(a) shows the waveforms when $S_{\mathrm{B} 1}$ is turned on before $S_{\mathrm{P} 1}$ turns on. The cell voltage $v_{C 2}$ is applied to the balance resistor from the time $\mathrm{S}_{\mathrm{B} 1}$ turns on until $\mathrm{S}_{\mathrm{P} 1}$ turns on. This causes a short-circuit on $C_{C 2}$, and a large current flows in the balancing circuit. Figure 8 (b) shows the waveforms when $S_{P 1}$ is turned on before $\mathrm{S}_{\mathrm{B} 1}$ turns on. When $\mathrm{S}_{\mathrm{P} 1}$ turns on, the body diode of $\mathrm{S}_{\mathrm{N} 1}$ turns off. Then, even after $S_{B 1}$ turns on, there is no short-circuit in
$C_{C 2}$, and the loss in the balancing circuit does not increase. This commutation sequence can be achieved just by adjusting the gate resistance to change the turn on/off delay time of balance switch $\mathrm{S}_{\mathrm{B}}$. For more details, see section 6.3.

\section{Verification of Loss due to Switching Ripple Voltage}

To verify the loss reduction achieved by designing and operating the balancing circuit with LSB, a simulation is performed to calculate the loss in the balancing circuit using the circuits shown in Figs. 1 and 2. The evaluation was focused only on the loss due to switching ripple voltage. Therefore, ideal switching conditions were assumed so that there is no unbalanced voltage due to the variation among the switches nor switching loss, and the short-circuit of the cell capacitor does not occur. The parameters used in the analysis were set as AC voltage $\sqrt{3} V_{s}=200 \mathrm{~V}$ and $V_{d c}=350 \mathrm{~V}$, and the switching frequency $f_{s w}$ was $1 \mathrm{kHz}$. The capacitance of the cell capacitor was set to $3.7 \mathrm{mF}$ so that the voltage ripple width of the cell capacitor was $10 \%$. Both voltage and current reference values of the converter arm are provided with the waveforms that appear at the steady-state operation in the MMC.

Figure 9 shows the simulation results of the loss ratio of the balancing circuit and the rms value of the balance current with HSB. The loss ratio is the rate of the total loss in all the balancing circuits to the rated converter power. The balance resistance value $R_{B}$ was set relatively low so that the time constant $\tau_{B}$ was 0.05 to 0.075 times the switching period $t_{s w}$. Although the loss ratio of the balancing circuit increases proportionally to the output power, the loss ratio does not almost change even when the resistance value $R_{B}$ decreases to $2 / 3$. The rms value of the balance current indicates that it is about $40 \%$ of the rms value of current in the main switch. Therefore, the current rating of the balance switch requires about half of the main switch.

Figure 10 shows the simulation results of the loss ratio of the balancing circuit and the rms value of the balance current

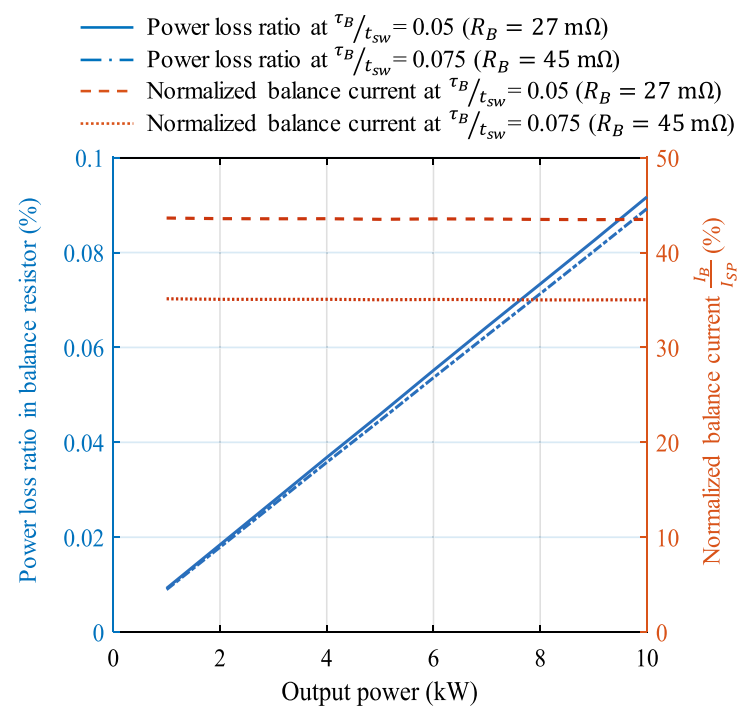

Fig. 9. Power loss and balance current at the steady state in case of HSB obtained by simulation 


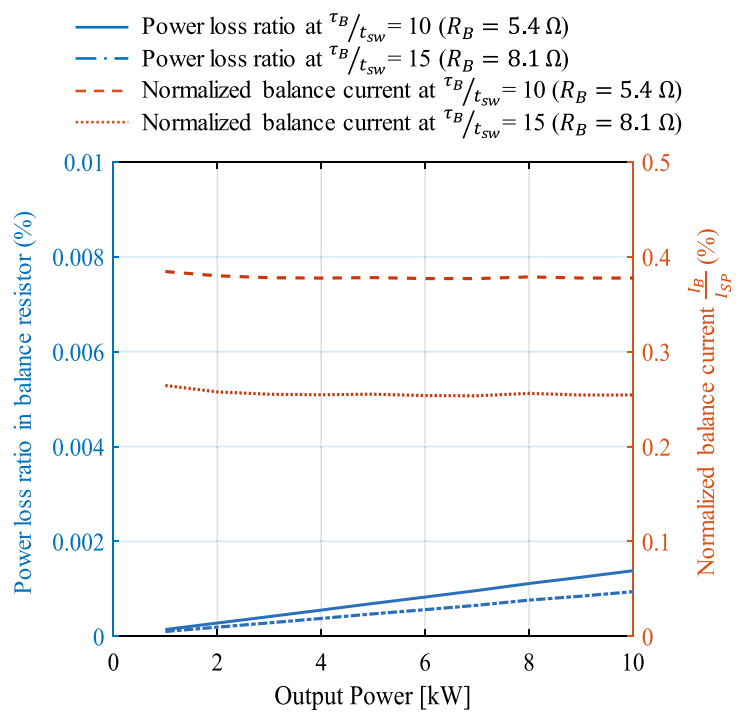

Fig. 10. Power loss and balance current at the steady state in case of LSB obtained by simulation

with LSB. The balance resistance value $R_{B}$ was set larger than HSB. The time constant $\tau_{B}$ of LSB was set between 100 and $150 \mathrm{~ms}$, which is 10 to 15 times the switching period $t_{s w}$. Except for $R_{B}$, the same parameters as shown in Fig. 9 were used. Compared to the case with HSB, the loss ratio of the balancing circuits is as small as $0.001 \%$, which is equivalent to reduction about $1 / 60$ to $1 / 90$. The rms value of the balance current is also less than $0.4 \%$ compared to that of the main switch, which allows the balance switch with a small current rating to be applied.

The simulation results confirm that it is possible to reduce the losses due to switching ripple voltage, as well as the current rating of the balance switches by designing a balancing circuit as LSB condition.

\section{Experimental Results}

6.1 Experimental System The proposed balancing circuit can be applied not only to conventional MMCs but also to other types of MMCs with a converter arm. An NPC$\mathrm{MMC}$ has a half number of the cell capacitor compared to a conventional $\mathrm{MMC}^{(6)}$ and hence it is good to apply to a lowvoltage grid-connected converter, which is mainly focused in this paper. In the experiment, a proposed balancing circuit is connected to the chopper-cells of the NPC-MMC.

Figure 11 shows the configuration of the experimental circuit, and Table 2 lists the circuit parameters. Note that, due to the conveniences of the experimental setup, the directions of $i_{\text {armP }}$ and $i_{\text {arm } N}$ in Fig. 11 are inverted to that of the $i_{\text {arm }}$ discussed until the last section. The NPC-MMC has a three-level structure consisting of a converter arm, four highvoltage switches, and two DC capacitors. The high-voltage switch is synchronized with the grid voltage. The converter arm outputs the grid voltage or the voltage difference between the grid voltage and the DC capacitor voltage, that depending on the state of the high-voltage switch. The voltage reference of the converter arm and arm current on the positive side is expressed as follows:

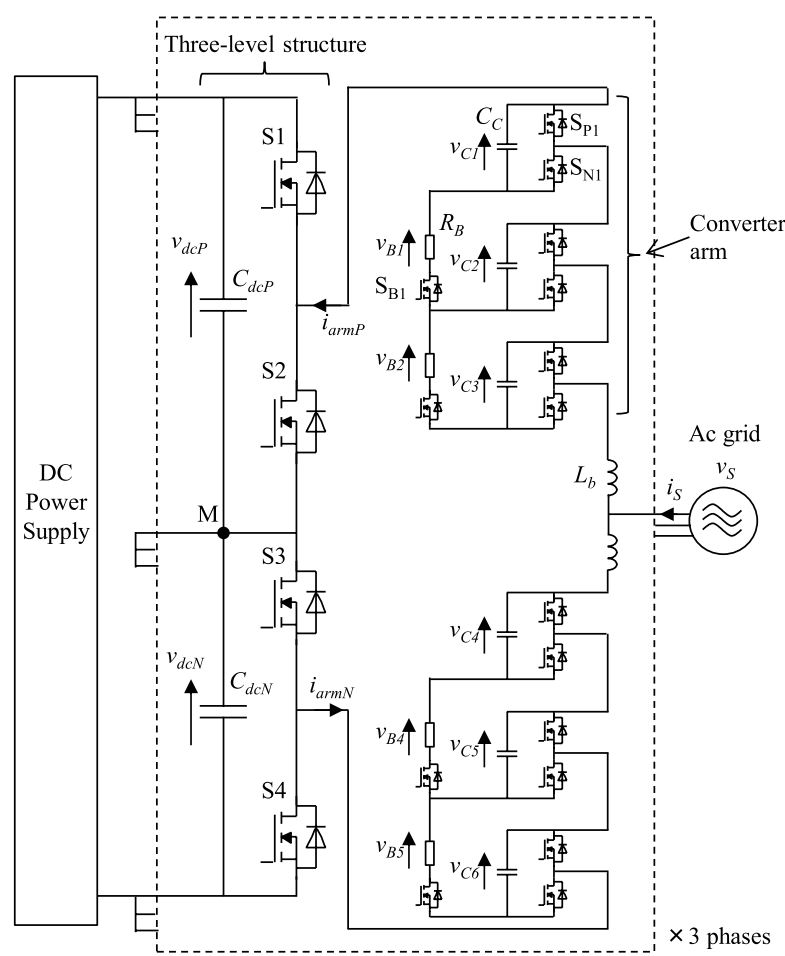

Fig. 11. Experimental circuit of NPC-MMC with balancing circuit

Table 2. Parameters of the experimental circuit

\begin{tabular}{l|c|c}
\hline \hline Rated power & $P$ & $10 \mathrm{kVA}$ \\
\hline Line-to-line grid voltage & $\sqrt{3} V_{s}$ & $200 \mathrm{~V}$ \\
\hline Rated ac grid current & $I_{S}$ & $28.9 \mathrm{~A}$ \\
\hline Rated circulating current & $I_{Z}$ & $6.1 \mathrm{~A}$ \\
\hline System frequency & $f$ & $50 \mathrm{~Hz}$ \\
\hline Dc link voltage & $V_{d c}$ & $350 \mathrm{~V}$ \\
\hline Cell capacitor & $C_{C}$ & $8 \mathrm{mF}$ \\
\hline Cell capacitor voltage & $V_{C 0}$ & $58 \mathrm{~V}$ \\
\hline Balance resistor & $R_{B}$ & $15 \Omega$ \\
\hline Dc capacitor in one phase & $C_{d c P}, C_{d c N}$ & $0.8 \mathrm{mF}$ \\
\hline Dc capacitor voltage & $V_{d c P}, V_{d c N}$ & $175 \mathrm{~V}$ \\
\hline Buffer inductor & $L_{b}$ & $0.1 \mathrm{mH}$ \\
\hline Switching frequency of the cell & $f_{s w}$ & $6.6 \mathrm{kHz}$ \\
\hline Number of cells & $N$ & 3 \\
\hline \hline
\end{tabular}

$$
\begin{aligned}
& v_{\text {armP }}{ }^{*} \\
& = \begin{cases}\frac{V_{d c}}{2}-v_{s} & \ldots 2 n \pi \leq \omega t<(2 n+1) \pi \\
-v_{s} & \ldots(2 n+1) \pi \leq \omega t<2(n+1) \pi\end{cases} \\
& i_{\text {armP }}=\frac{i_{s}}{2}+I_{Z}
\end{aligned}
$$

where $V_{d c}$ is the DC link voltage, $v_{s}$ is AC phase voltage, $i_{s}$ is $\mathrm{AC}$ current, and $I_{Z}$ is DC circulating current ${ }^{(6)}$.

Figure 12 shows the circuit board of the NPC-MMC where the balancing circuit was connected. In the experimental circuit, each cell capacitor is equipped with a voltage detection sensor, but the control was performed with only the voltage signal $v_{C 1}$ on the positive side arm and $v_{C 4}$ on the negative side arm. The cells in the same arm were operated by the same duty ratio. For example, the duty ratio of $\mathrm{S}_{\mathrm{P} 1}$ can be obtained with $v_{C 1}$ as follows: 


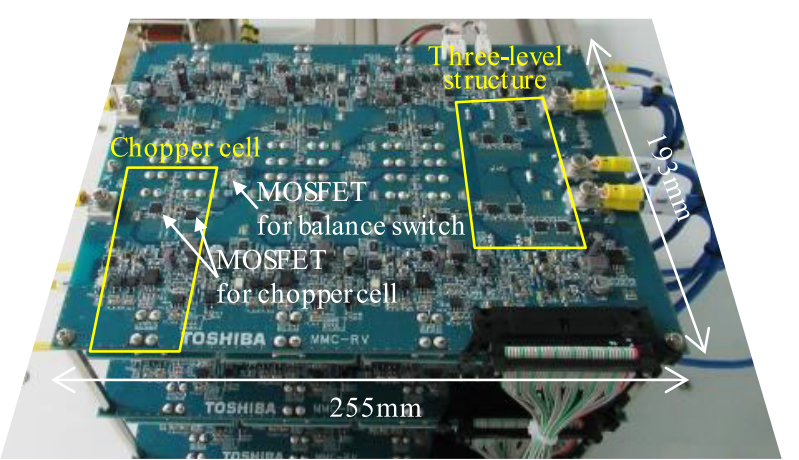

Fig. 12. Experimental circuit board of an NPC-MMC with balance circuit

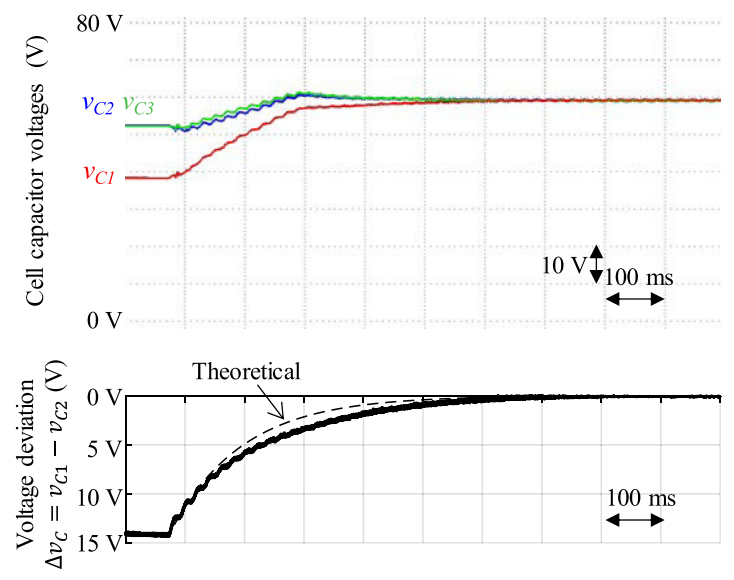

Fig. 13. Experimental waveforms of damping the voltage deviation

$$
D_{S P 1}=D_{S P 2}=D_{S P 3}=1-D_{S N 1}=1-\frac{v_{a r m P}{ }^{*}}{N v_{C 1}} \cdots \cdots
$$

The gate signals were generated with phase-shifted PWM and given to the switching devices of each cell. The gate signal given to balance switch $S_{B}$ was distributed from the gate signal line of the main switch $S_{P}$, as shown in Fig. 3. Using Eq. (13), the balance resistor was set to $15 \Omega$ so that $\tau_{B}$ was $120 \mathrm{~ms}$. It was calculated from Eqs. (14) and (16), with $\overline{D_{S P}}$ (the average duty ratio of $S_{P}$ ) as 0.5 . The time constant of the balancing circuit for the experiment was considerably longer than the switching cycle, and thus the experimental circuit operates as LSB condition $\left(\tau=60 \mathrm{~ms} \gg 1 / f_{s w}=0.15 \mathrm{~ms}\right)$.

6.2 Verification of the Unbalanced Voltage Suppression Figure 13 shows the waveform at the startup when the balancing circuit is connected. A discharging resistor $(2.2 \mathrm{k} \Omega)$ was intentionally connected in parallel to the cell capacitor of the uppermost cell in the upper arm of U-phase to generate unbalanced voltage. Before switching starts, the cell capacitor voltage was unbalanced. Starting the switching, the unbalanced voltage was quickly decreased. The experimental results were in agreement with the theoretical curve expressed by Eq. (13). It is confirmed that it balances with the designed time constant. Also, even when there was a voltage difference of about $14 \mathrm{~V}$ (24\%) right after the startup, considering that $R_{B}=15 \Omega$, the current that flows in the balance resistor is $0.93 \mathrm{~A}$. The peak value of the balance switch current was suppressed to as little as $3.8 \%$ of the main switch.

Figures 14 and 15 show the waveforms of converter and

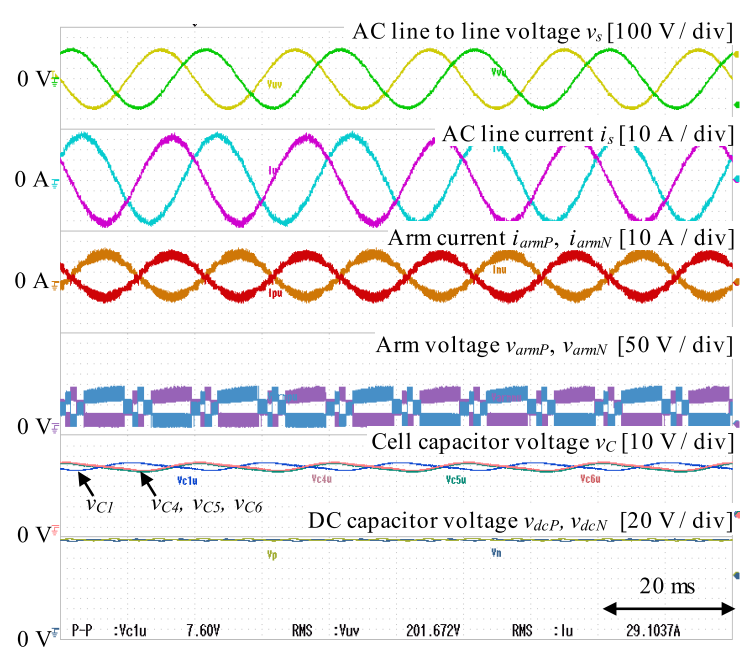

Fig. 14. Experimental waveforms in the rectifier operation at steady state
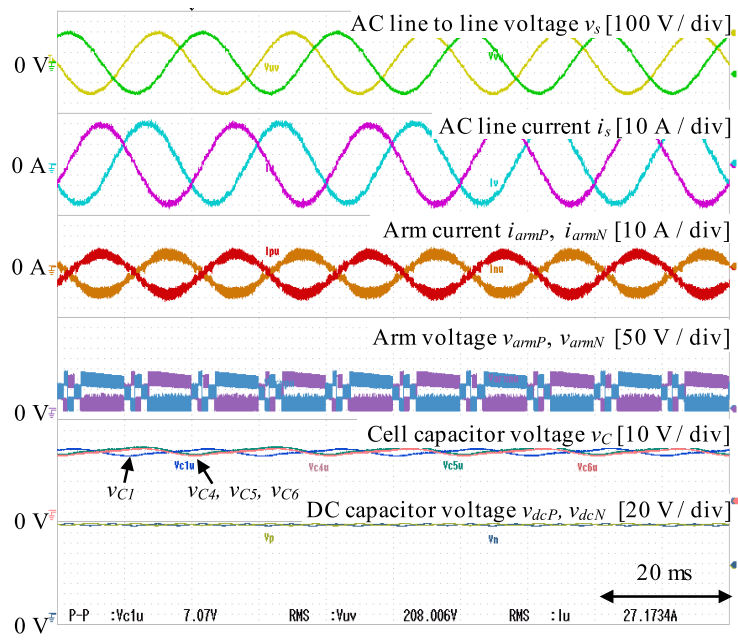

Fig. 15. Experimental waveforms in the inverter operation at steady state

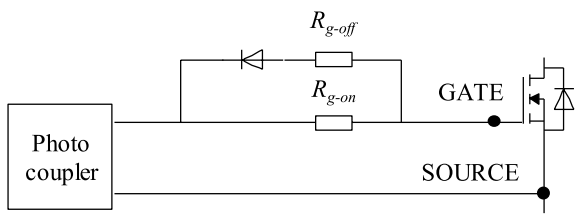

Fig. 16. Gate driver circuit

inverter operations with a rated power of $10 \mathrm{~kW}$. The grid current of the NPC-MMC with the balancing circuit is controlled as a sine wave in both operations. All cell capacitors in the same arm have the same voltage, which confirms that the proposed balancing circuit can effectively suppress the unbalanced voltage.

6.3 Experimental Verification of Short-circuit Loss Reduction An experiment was conducted to confirm that the loss due to short-circuit of the cell capacitor can be reduced by changing the commutation sequence of balance switch. In the experiment, as illustrated in Fig. 3, $\mathrm{S}_{\mathrm{P}}$ and $S_{B}$ were operated by the same gate signal. To prevent short-circuit current from damaging the switching device, the same MOSFET used in $S_{P}$ and $S_{N}$, and $S_{B}$. Figure 16 shows the gate drive circuit. The turn on/off delay time of 


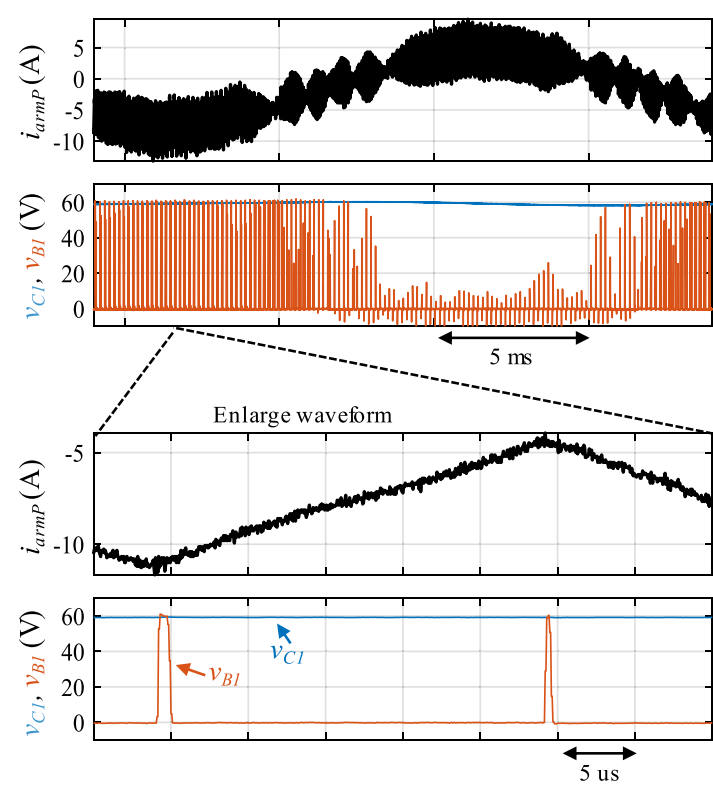

Fig. 17. Experimental waveforms of balancing circuit occurring a short circuit of cell capacitor

$\mathrm{S}_{\mathrm{P}}$ and $\mathrm{S}_{\mathrm{B}}-T_{d-o n(S P)}, T_{d-o f f(S P)}, T_{d-o n(S B)}$, and $T_{d-o f f(S B)}-$ can respectively be adjusted by the gate resistance $R_{g-o n}$ and $R_{g-o f f}$. By choosing $R_{g-o n}$ and $R_{g-o f f}$ of $\mathrm{S}_{\mathrm{P}}$ and $\mathrm{S}_{\mathrm{B}}$ adequately, it is possible to change the switching timing. For the commutation sequence preventing a short-circuit of the cell capacitor as shown in Fig. 8(b), the delay times were set to $T_{d-o n(S B)}>$ $T_{d-o n(S P)}$ and $T_{d-o f f(S P)}>T_{d-o f f(S B)}$. For comparison, the commutation sequence that causes short-circuit of the cell capacitor as shown in Fig. 8(a) was carried by setting to $T_{d-o n(S P)}$ $>T_{d-o n(S B)}$ and $T_{d-o f f(S B)}>T_{d-o f f(S P)}$. Generally, when $R_{g-o n}$ is increased, switching loss increases, and when $R_{g-o f f}$ is decreased, switching surge increases. However, in the LSB operation, the current that flows in the balance switch becomes considerably smaller than the main switch, and both switching loss and surge voltage are too small to cause problems.

Figure 17 shows the waveform of the balancing circuit when a short-circuit of the cell capacitor occurred in the switching. To prevent the balance resistor from heating up due to the short-circuit current, it was measured with an output of $3 \mathrm{~kW}$. The voltage of the cell capacitor was applied to the balance resistor during the interval of about $1 \mu \mathrm{s}$. When the short-circuit occurred, there was a loss in the balance resistor. This loss, calculated from the waveform of $v_{B 1}$, was $0.83 \mathrm{~W}$ per balance resistor.

Figure 18 shows the waveform with a rated output of $10 \mathrm{~kW}$ when a short-circuit of the cell capacitor is prevented in the switching. Almost no voltage was applied to the balance resistor. The loss generated in each balance resistor, calculated from the waveform of $v_{B 4}$, was drastically reduced to $0.034 \mathrm{~W}$. Furthermore, changing the switching speed of the balance switch by gate resistance did not lead to a significant increase in switching loss or surge voltage.

\subsection{Experimental Verification of Conversion Loss}

Figure 19 shows the conversion loss measured by DC power $P_{d c}$ and AC power $P_{a c}$. The conversion loss includes the loss in the main switches and cell capacitors, gate circuits, and buffer reactors. The red " $\mathrm{x}$ " marker represents
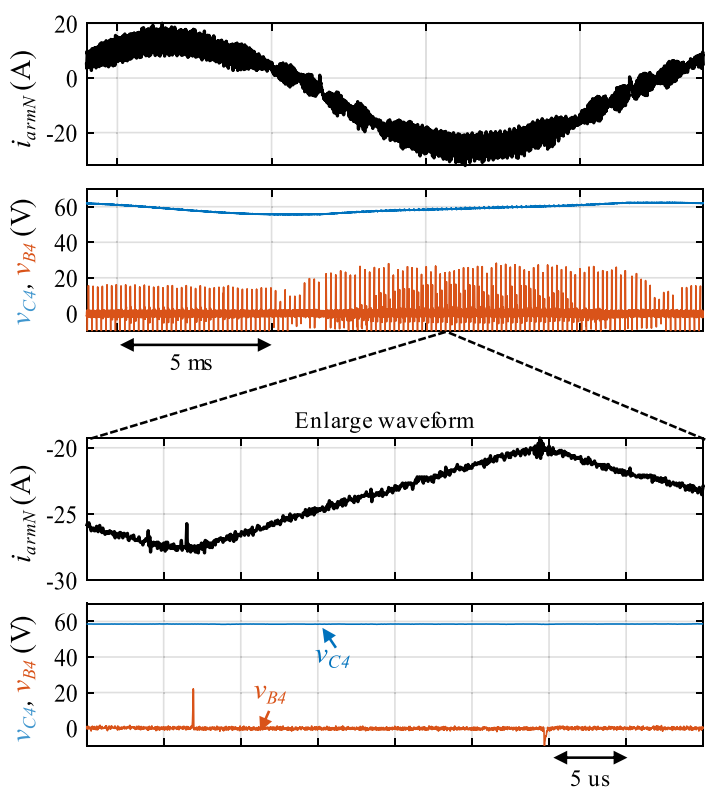

Fig. 18. Experimental waveforms of balancing circuit preventing a short circuit of cell capacitor

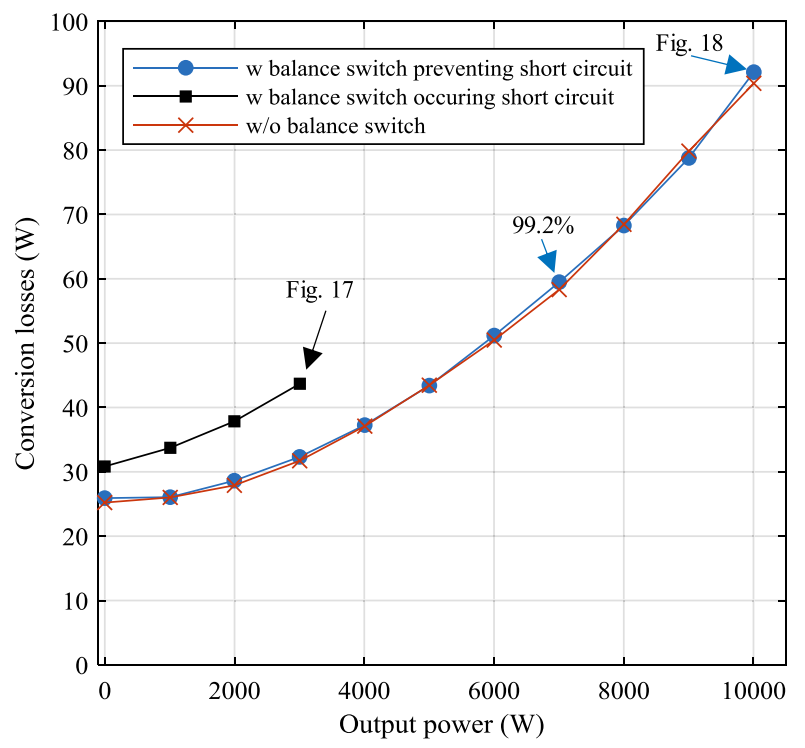

Fig. 19. Comparison of conversion losses

the conversion loss when the balancing circuit is disconnected, and individual voltage balance control was performed by feedback control. The black marker and the blue marker represent the conversion loss when the balancing circuit is connected. The black marker shows a short-circuit of the cell capacitor occurred, as shown in Fig. 17. The blue - marker represents when the commutation sequence to prevent short-circuit of Fig. 18 was applied.

Even when the same balancing circuit was connected to the NPC-MMC, the proposed commutation sequence that prevents short-circuits can reduce the loss with an output of $3 \mathrm{~kW}$ by $11.4 \mathrm{~W}$. The loss per one balance resistor calculated from Fig. 17 was $0.83 \mathrm{~W}$. The experimental circuit of the NPC-MMC has 12 balance resistors, and assuming all of them generate the same loss, the total loss was estimated of $10.0 \mathrm{~W}$ ( $=0.83 \mathrm{~W} \times 12$ units $)$, which matches the difference in measured conversion loss. 
When short-circuit of the cell capacitor was prevented, the conversion loss from low output power to rated output power hardly increased compared to that of applied the individual voltage balance control. This result indicates that the ratio of the loss caused by the balancing circuit to the conversion loss of NPC-MMC was small. That is, there was hardly any loss due to switching ripple voltage or short-circuit. Therefore, the experiment demonstrated that the proposed circuit can reduce the loss in the balancing circuit significantly without increasing the capacitance of the cell capacitor, with a highly efficient power conversion of up to $99.2 \%$.

\section{Conclusion}

In this paper, a balancing circuit with resistor, which is designed to balance the cell capacitor voltage and reduce the loss of the balancing circuit, was proposed. The analysis and simulation showed that the proposed balancing circuit can reduce the loss due to switching ripple voltage and the current rating of the balance switch without increasing the capacitance of the cell capacitor by balance resistor. It is also possible to reduce the loss due to short-circuit of the cell capacitor by turning the balance switch on later and turning it off earlier to the main switch. In the experiment, the proposed balancing circuit was connected to the chopper-cells of an NPC-MMC of $10 \mathrm{~kW}$. The experimental results confirmed that the cell capacitor voltage in operation was well balanced, and little loss increased due to the connection of the balancing circuit. The conversion efficiency of the converter, including the balancing circuit, was achieved of $99.2 \%$.

\section{References}

(1) A. Lesnicar and R. Marquardt: "An innovative modular multilevel converter topology suitable for a wide power range", Proc. IEEE Bologna Power Tech Conf., Vol.3, pp.1-6 (2003)

( 2 ) S. Allebrod, R. Hamerski, and R. Marquardt: "New transformerless, scalable modular multilevel converters for HVDC-transmission", in Conf. Rec. IEEE Power Electronics Spec. Conf., pp.174-179 (2008)

( 3 ) B. Gemmell, J. Dorn, D. Retzmann, and D. Soerangr: "Prospects of multilevel VSC technologies for power transmission", in Conf. Rec. IEEETDCE, pp.1-16 (2008)

( 4 ) H. Akagi: "Classification, terminology, and application of the modular multilevel cascade converter (MMCC)", IEEE Trans. Power Electron., Vol.26, No.11, pp.3119-3130 (2011)

( 5 ) Y. Kashihara and J. Itoh: "Power losses of multilevel converters in terms of the number of the output voltage levels", Proc. Int. Power Electron. Conf., pp.1943-1949 (2014)

( 6 ) T. Arai, K. Sekiguchi, H. Mochikawa, K. Sano, and H. Fujita: "Evaluation of Required Energy Storage in Neutral-Point-Clamped Modular Multilevel Converter for Downsizing Low-Voltage Grid Converters", IEEE Trans. Power Electron., Vol.36, No.6, pp.6774-6786 (2021)

( 7 ) A. Antonopoulos, L. Ngquist, and H.-P. Nee: "On dynamics and voltage control of the modular multilevel converter", Proc. 13th Eur. Conf. Power Electron. Appl., pp.1-10 (2009)

( 8 ) M. Hagiwara and H. Akagi: "PWM Control and Experiment of Modular Multilevel Converters", IEEJ Trans. Ind. Appl., Vol.128-D, No.7, pp.957965 (2008) (in Japanese)

( 9 ) F.Z. Peng, J.-S. Lai, J.W. McKeever, and J. VanCoevering: "A multilevel voltage-source inverter with separate DC sources for static VAr generation", IEEE Trans. Ind. Appl., Vol.32, No.5, pp.1130-1138 (1996)

(10) P.M. Meshram and V.B. Borghate: "A simplified nearest level control (NLC) voltage balancing method for modular multilevel converter (MMC)", IEEE Trans. Power Electron., Vol.30, No.1, pp.450-462 (2015)

(11) R. Darus, J. Pou, G. Konstantinou, S. Ceballos, R. Picas, and V.G. Agelidis: "A modified voltage balancing algorithm for the modular multilevel converter: evaluation for staircase and phase-disposition PWM", IEEE Trans. Power Electron., Vol.30, No.8, pp.4119-4127 (2015)
(12) H. Peng, R. Xie, K. Wang, Y. Deng, X. He, and R. Zhao: "A capacitor voltage balancing method with fundamental sorting frequency for modular multilevel converters under staircase modulation", IEEE Trans. Power Electron., Vol.31, No.11, pp.7809-7822 (2016)

(13) K. Ilves, A. Antonopoulos, S. Norrga, and H. Nee: "A new modulation method for the modular multilevel converter allowing fundamental switching frequency", IEEE Trans. Power Electron., Vol.27, No.8, pp.3482-3494 (2012)

(14) K. Ilves, L. Harnefors, S. Norrga, and H. Nee: "Predictive sorting algorithm for modular multilevel converters minimizing the spread in the submodule capacitor voltages", IEEE Trans. Power Electron., Vol.30, No.1, pp.440-449 (2015)

(15) K.H. Ahmed and G.P. Adam: "New modified staircase modulation and capacitor balancing strategy of 21-level modular multilevel converter for HVDC transmission systems", Proc. 7th IET Int. Conf. Power Electron. Mach. Drives, pp.1-6 (2014)

(16) A. Elserougi, M.I. Daoud, A.M. Massoud, A.S. Abdel-Khalik, and S. Ahmed: "Investigation of sensorless capacitor voltage balancing technique for modular multilevel converters", Proc. 40th Annu. Conf. IEEE Ind. Electron. Soc., pp.1569-1574 (2014)

(17) A. Ghazanfari and Y.A.-R.I. Mohamed: "A hierarchical permutation cyclic coding strategy for sensorless capacitor voltage balancing in modular multilevel converters", IEEE J. Emerg. Sel. Top. Power Electron., Vol.4, No.2, pp.576-588 (2016)

(18) Y. Liu and F.Z. Peng: "A four-level modular multilevel converter with self voltage balancing and extremely small dc capacitor", Applied Power Electronics Conference and Exposition (APEC) 2019 IEEE, Anaheim, CA, USA, pp.2865-2871 (2019)

(19) F.Z. Peng: "A generalized multilevel inverter topology with self voltage balancing", IEEE Trans. Ind. Appl., Vol.37, No.2, pp.611-618 (2001)

(20) J.I. Rodriguez and S.B. Leeb: "A Multilevel Inverter Topology for Inductively Coupled Power Transfer", IEEE Trans. Power Electron., Vol.21, No.6, pp.1607-1617 (2006)

(21) F.Z. Peng, W. Qian, and D. Cao: "Recent advances in multilevel converter/inverter topologies and applications", in Proc. Int. Power Electron. Conf., pp.492-501 (2010)

(22) Y. Hinago and H. Koizumi: "A Switched-Capacitor Inverter Using Series/Parallel Conversion with Inductive Load", in IEEE Transactions on Industrial Electronics, Vol.59, No.2, pp.878-887 (2012)

(23) R.S. Alishah, S.H. Hosseini, E. Babaei, and M. Sabahi: "A New General Multilevel Converter Topology Based on Cascaded Connection of Submultilevel Units With Reduced Switching Components, DC Sources, and Blocked Voltage by Switches", in IEEE Transactions on Industrial Electronics, Vol.63, No.11, pp.7157-7164 (2016)

(24) A. Taghvaie, J. Adabi, and M. Rezanejad: "A Self-Balanced Step-Up Multilevel Inverter Based on Switched-Capacitor Structure", IEEE Trans. Power Electron., Vol.33, No.1, pp.199-209 (2018)

(25) X. Liu, et al.: "A Novel Diode-Clamped Modular Multilevel Converter with Simplified Capacitor Voltage-Balancing Control", in IEEE Transactions on Industrial Electronics, Vol.64, No.11, pp.8843-8854 (2017)

(26) F.Z. Peng, F. Zhang, and Z. Qian: "A magnetic-less dc-dc converter for dualvoltage automotive systems", IEEE Trans. Ind. Appl., Vol.39, No.2, pp.511518 (2003)

(27) R. Hasegawa, S. Tashiro, and D. Suzuki: "A Proposal of Control Method for Regulating Capacitor Voltages of Neutral Point Clamped Modular Multilevel Converter", PCIM Asia 2017; International Exhibition and Conference for Power Electronics, Intelligent Motion, Renewable Energy and Energy Management, pp.1-6 (2017)

(28) K. Sekiguchi, M. Nitta, M. Hagiwara, and H. Akagi: "Discussion on Triangular-Carrier Frequencies of a Modular Multilevel Cascade Converter Based on Double-Star Chopper Cells (MMCC-DSCC) with Phase-Shifted PWM", IEEJ Trans. Ind. Appl., Vol.134-D, No.10, pp.890-903 (2014) (in Japanese)

Takuro Arai (Member) was born in Tokyo, Japan, in 1987. He re-

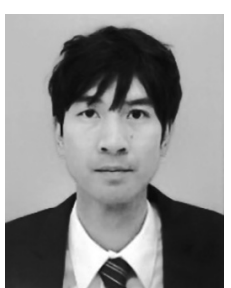
ceived the B.S., M.S., and Ph.D. degree in electrical and electronic engineering from the Tokyo Institute of Technology, Tokyo, Japan, in 2010, 2012, and 2021 respectively. Since April 2012, he has been with Toshiba Corporation, Tokyo, Japan. His research interests include grid-connected converters, multilevel converter topology, and control. He received 2020 IEEJ Technical Development Award. 
Kei Sekiguchi (Member) was born in Saitama, Japan, in 1990. He

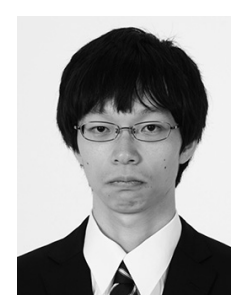
received the B.S. and M.S. degrees in electrical and electronic engineering from the Tokyo Institute of Technology, Tokyo, Japan, in 2012 and 2014, respectively. Since April 2014, he has been with Toshiba Corporation, Tokyo. His research interests include power-electronics converter topology, modeling, and control. He received the 2014 IEEE Industry Applications Society Industrial Power Converter Committee First Prize Paper Award.

Hiroshi Mochikawa (Senior Member) was born in Niigata, Japan,

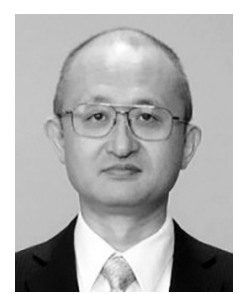
in 1982. He received the B.S. and M.S. degrees in electrical and electronics engineering from Nagaoka University of Technology, Niigata, Japan, in 1983 and 1985, respectively. In 1985, he joined Toshiba Corporation, Tokyo, Japan. He has been engaged in high efficiency converters and EMI/EMC. He received $54^{\text {th }}$ Promotion for Electrical Science and Engineering Award and 2008 IEEJ Technical Development Award.

Kenichiro Sano

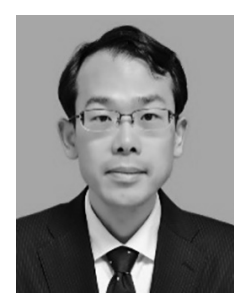

(Member) received the B.S. degree in international development engineering and the M.S. and Ph.D. degrees in electrical and electronic engineering from the Tokyo Institute of Technology, Tokyo, Japan, in 2005, 2007, and 2010, respectively. From 2008 to 2010, he was a JSPS Research Fellow. In 2008, he was a Visiting Scholar at the Virginia Polytechnic Institute and State University, Blacksburg, VA, USA. From 2010 to 2018, he was a Research Scientist at the Central Research Institute of Electric Power Industry, Yokosuka, Japan. In 2018, he joined the Tokyo Institute of Technology, where he is currently an Assistant Professor with the Department of Electrical and Electronic Engineering. His current research interests include power electronics for utility applications, high-voltage dc transmission systems, and power system quality. He received 2019 IEEJ Distinguished Paper Award.
Hideaki Fujita (Member) received the B.S. and M.S. degrees from

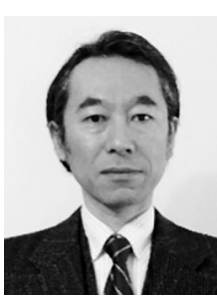
the Nagaoka University of Technology, Niigata, Japan, in 1988 and 1990, respectively, and the Dr.Eng. degree from the Tokyo Institute of Technology, Tokyo, Japan, in 2000, all in electrical engineering. He joined Okayama University, Okayama, Japan, in 1991, as a Research Associate. He became an Associate Professor in 2002 and a Professor in 2018 at the Department of Electrical Engineering, Tokyo Institute of Technology. His research interests include high-frequency inverters for industrial induction heating, power converters for solar and wind power generations, and multilevel converters. Dr. Fujita received the five Committee Prize Paper Awards from the IEEE Industry Applications Society Industrial Power Converter Committee in 1990, 1995, 1998, 2003, and 2016, and a Society Prize Paper Award from the IEEE Industry Applications Society in 2009. He received the 2005 Isao Takahashi Power Electronics Award presented by the Institute of Electrical Engineers of Japan at the International Power Electronics Conference (IPEC-Niigata 2005). He received the IEEJ Distinguished Paper Award in 2008, and the IEEJ Industry Applications Society Distinguished Transaction Paper Award in 2010 . 